\title{
Different propagules and auxin concentration on rooting of passionflower sandbank
}

\author{
Rodrigo Sobreira Alexandre ${ }^{1 *}$, Poliana Rangel Costa ${ }^{2}$, Kristhiano Chagas $^{3}$, Livia Giro Mayrinck ${ }^{2}$, \\ João Antônio Dutra Giles ${ }^{2}$ Edilson Romais Schmildt ${ }^{2}$
}

$10.1590 / 0034-737 X 201663050014$

\begin{abstract}
Passiflora mucronata Lam. is resistant to Fusarim oxysporum f. passifloraceae and therefore can be used as rootstock for the species Passiflora edulis Sims. f. flavicarpa. The rootstocks in this case can be vegetatively propagated through cuttings. The objective of this study was to evaluate the effect of different types of cuttings and different concentrations of indole-3-butyric acid (IBA) on the adventitious rooting of P. mucronata. The experiments were arranged in a completely randomized design with four replications of 16 cuttings each. In Experiment 1, the treatments consisted of the different types of cuttings from mother plants grown in protected environment: shoot tips; two leaves and two nodes; one leaf and one node; leafless with two nodes; leafless with one node. In Experiment 2, the cuttings were taken from field plants and treated with the following IBA concentrations: $0 ; 1000 \mathrm{mg} \mathrm{kg}^{-1}\left(0.0036456 \mathrm{~mol} \mathrm{~L}^{-1}\right) ; 1500$ $\mathrm{mg} \mathrm{kg}^{-1}\left(0.0054684 \mathrm{~mol} \mathrm{~L}^{-1}\right)$ and $2000 \mathrm{mg} \mathrm{kg}^{-1}\left(0.0072912 \mathrm{~mol} \mathrm{~L}^{-1}\right)$. The characteristics evaluated in the experiments 1 and 2 were: survival (1 and 2); budding (1 and 2); shoot number (2), shoot length (2), number of shoot leaves (2);shoot dry mass (2); callusing (1); rooting (1 and 2); root number (1 and 2), largest root length (1 and 2), root volume (1 and 2), and root dry mass (1 and 2). We found that, instead the shoot tips, the cuttings of the type leafless with two nodes are the best for P. mucronata rooting. Neither the cuttings from greenhouse plants nor the cuttings from field plants require growth regulators for rooting of $P$. mucronata cuttings of the type leafless with two nodes.
\end{abstract}

Keywords: Passiflora mucronata Lam.; vegetative propagation; cutting; auxin.

\section{RESUMO}

\section{Diferentes propágulos e concentrações de auxina no enraizamento de maracujazeiro-de-restinga}

A espécie Passiflora mucronata Lam. é identificada como resistente ao Fusarim oxysporum f. passifloraceae e, portanto, pode ser utilizada como porta-enxerto para a espécie Passiflora edulis Sims. f. flavicarpa Deg., e a obtenção desses porta-enxertos pode dar-se por propagação vegetativa por estaquia. Objetivou-se, com este trabalho, avaliar diferentes tipos de estacas e diferentes concentrações do ácido indol-3-butírico (AIB), no enraizamento adventício de $P$. mucronata. Os experimentos foram realizados em delineamento inteiramente casualizado, com quatro repetições, de 16 estacas cada. No primeiro experimento, os tratamentos foram os diferentes tipos de estacas de plantas-matrizes de ambiente protegido: apical; de duas folhas e dois nós; de uma folha e um nó; sem folhas e dois nós; sem folhas e um nó. No segundo experimento, as estacas foram retiradas de campo e os tratamentos foram as concentrações de AIB: 0; 1000 $\left(0,0036456 \mathrm{~mol} \mathrm{~L}^{-1}\right) ; 1500\left(0,0054684 \mathrm{~mol} \mathrm{~L}^{-1}\right)$ e $2000 \mathrm{mg} \mathrm{kg}^{-1}\left(0,0072912 \mathrm{~mol} \mathrm{~L}^{-1}\right)$. As características avaliadas no primeiro $\left(1^{\circ}\right)$ e no segundo $\left(2^{\circ}\right)$ experimentos foram: sobrevivência $\left(1^{\circ}\right.$ e $\left.2^{\circ}\right)$; brotação $\left(1^{\circ}\right.$ e $\left.2^{\circ}\right)$; número $\left(2^{\circ}\right)$, comprimento $\left(2^{\circ}\right)$,

\footnotetext{
Submitted on november 27th, 2014 and accepted on May $23^{\text {th }}, 2016$.

${ }^{1}$ Universidade Federal do Espírito Santo, Departamento de Ciências Florestais e da Madeira, Jerônimo Monteiro, Espírito Santo, Brazil. rodrigosobreiraalexandre@gmail.com ${ }^{2}$ Universidade Federal do Espírito Santo, Departamento de Ciências Agrárias e Biológicas, São Mateus, Espírito Santo, Brazil. poli.rangel@hotmail.com; joao_antoniodg@hotmail.com; lgmayrinck@hotmail.com

${ }^{3}$ Universidade Federal de Viçosa, Departamento de Biologia Vegetal, Viçosa, Minas Gerais, Brazil. kristhianoc@gmail.com

*Corresponding author: rodrigosobreiraalexandre@gmail.com
} 
número de folhas $\left(2^{\circ}\right)$ e massa seca do broto $\left(2^{\circ}\right)$; calejamento $\left(1^{\circ}\right)$; enraizamento $\left(1^{\circ}\right.$ e $\left.2^{\circ}\right)$; número $\left(1^{\circ}\right.$ e $\left.2^{\circ}\right)$, comprimento $\left(1^{\circ}\right.$ e $\left.2^{\circ}\right)$, volume $\left(1^{\circ}\right.$ e $\left.2^{\circ}\right)$ e massa seca de raiz $\left(1^{\circ}\right.$ e $\left.2^{\circ}\right)$. Recomenda-se usar estacas sem folhas e com dois nós, e não as apicais, para o processo de enraizamento de $P$. mucronata. O enraizamento das estacas sem folhas e com dois nós de $P$. mucronata dispensa o uso de reguladores de crescimento, tanto para as estacas provenientes de casa de vegetação quanto para as de campo.

Palavras-chave: Passiflora mucronata Lam.; propagação vegetativa; estaquia; auxina.

\section{INTRODUCTION}

Passiflora mucronata Lam. has been detected in the predominantly sandbank vegetation in the states of Espírito Santo and Rio de Janeiro (Magnago et al., 2011). This species is best adapted to more fertile soils (Lawrence Junior et al., 2013). Morphologically, it is considered an herbaceous (non-woody) vine with slender stem, twining, with touchsensitive tendrils that coil around a support (Barros et al., 2009). The species $P$. mucronata has great ornamental potential such as phosphorescent white flowers, with nocturnal anthesis for bat pollination, intense and almost continuous all year flowering (Meletti et al., 2011).

The species has medicinal properties and is used as sedative to treat insomnia, calming agent, anthelmintic and anti-hemorrhoidal (Boscolo \& Valle, 2008). Agriculturally, it stands out for its resistance to leaf bacterial blight and to be highly resistant to anthracnose of fruits and branches (Junqueira et al., 2005).

Passifloraceae species are kept in in field germplasm banks, and can be propagated by seeds or vegetatively, depending on the species.

The success of the propagation by cuttings depends on the capacity of forming roots, the quality of the root system and the subsequent plant development. Among the exogenous factors that affect rooting, the physiological conditions such as hormonal balance are considered the most important (Fachinello et al., 1995). However, morphological factors such as the presence or absence of nodes and leaves in the cuttings are also important. According to Hartmann et al. (2002), leaves and buds are sites of carbohydrates and auxin synthesis, respectively, which are key factors in stimulating the initiation of roots.

There is little literature information on the vegetative propagation of $P$. mucronata: we found only one published study with grafting reporting that the combination scionrootstock (P.edulis f. flavicarpa/P. mисronata) resulted in over $90 \%$ graft success, greater shoot height and greater internode growth than with the rootstocks $P$. alata, $P$. cincinnata Mast., $P$. gibertii N.E.Br., with autograft $(P$. edulis f. flavicarpa / P. edulis f. flavicarpa) and the ungrafted P. edulis f. flavicarpa (Morgado et al., 2015). In a study using mini-grafting, $P$. mucronata was grafted on
P. edulis f. flavicarpa with $80 \%$ graft success (Alexandre et al., 2013a), showing the new method efficiency.

The use of $P$. mucronata as rootstock for species $P$. edulis f. flavicarpa is very important, considering its resistance to Fusarim oxysporum f. passifloraceae (Oliveira et al., 2013). Rootstocks can be obtained by seeds or vegetative propagation, the latter being very important when resistant individuals are detected and the intention is to maintain their characteristics. Propagating P. mucronata vegetatively is important for several factors: the species does not bear fruit all year round; it has a small number of seeds per fruit; and its recalcitrant seeds (Santos et al., 2012a). According to Santos et al. (2012b), germination decreases over time, from zero to four months of storage.

Regarding the propagation by cuttings, only Alexandre et al. (2014) investigated the rooting ability of native $P$. mucronata plants, thus the need of more studies on the vegetative propagation of this species as an alternative of clonal rootstocks for $P$. edulis f. flavicarpa. Therefore, the objective of this study was to evaluate the effect of different types of cuttings and different concentrations of indole-3butyric acid (IBA) on the adventitious rooting of $P$. mucronata.

\section{MATERIAL AND METHODS}

The experiments were conducted in a greenhouse at the Experimental Farm of the Centro Universitário Norte do Espírito Santo (CEUNES), belonging to the Universidade Federal do Espírito Santo (UFES). Two experiments were carried out: the first, developed with plant cuttings grown in a greenhouse and the second, with cuttings of field plants.

\section{Experiment 1: Adventitious rooting of different types of adult cuttings from $P$. mucronata cultivated in greenhouse}

The plant material was obtained from Passiflora mucronata mother plants derived from vegetative propagation and grown in a greenhouse of the CEUNES/ UFES. This experiment complements the study developed by Alexander et al. (2014), with cuttings grown in the greenhouse. 
The treatments consisted of different types of cuttings: shoot tips; two leaves and two nodes; one leaf and one node; leafless with two nodes; leafless with one node. In this experiment, the cuttings were not treated with phytohormones. The leaves of the cuttings had their limbs halved and their botton ends were cut into a simple bevel.

\section{Experiment 2: Adventitious rooting of mature cuttings from field plants of $P$. mucronata and treated with IBA}

In this experiment, the type of cutting was chosen based on the results from experiment 1 , leafless cuttings with two nodes.

The treatments consisted of different concentrations of IBA $\left[0 ; 1000 \mathrm{mg} \mathrm{kg}^{-1}\left(0.0036456 \mathrm{~mol} \mathrm{~L}^{-1}\right) ; 1500 \mathrm{mg} \mathrm{kg}^{-1}\right.$ $\left(0.0054684 \mathrm{~mol} \mathrm{~L}^{-1}\right)$ and $\left.2000 \mathrm{mg} \mathrm{kg}^{-1}\left(0.0072912 \mathrm{~mol} \mathrm{~L}^{-1}\right)\right]$, using inert talc as vehicle, applied to the simple beveled base of leafless cuttings with two nodes.

In both experiments, the cuttings were planted in Bioplant ${ }^{\circledR}$ substrate filled into black polyethylene trays with the following cell dimensions: $54.4 \mathrm{~cm}$ long; $28.8 \mathrm{~cm}$ width; $12.5 \mathrm{~cm}$ and six-liter volume, divided into 32 equal sized cells.

The experiments were arranged in a completely randomized design with four replications of 16 cuttings each, totaling 64 cuttings per treatment. The characteristics evaluated in experiments 1 and 2 were: survival (1 and 2); budding (1 and 2); shoot number (2), shoot length (2), number of shoot leaves (2); shoot dry mass (2); callusing (1); rooting (1 and 2); root number (1 and 2), largest root length (1 and 2), root volume (1 and 2), and root dry mass (1 and 2).

Data were examined by analysis of variance and the means of the different types of cuttings (shoot tips; two leaves and two nodes; one leaf and one node; leafless with two nodes; leafless with one node (experiment 1)) were compared by the Tukey test and phenotypic correlation. The different concentrations of IBA [0; 1000 $\mathrm{mg} \mathrm{kg}^{-1}\left(0.0036456 \mathrm{~mol} \mathrm{~L}^{-1}\right) ; 1500 \mathrm{mg} \mathrm{kg}^{-1}(0.0054684 \mathrm{~mol} \mathrm{~L}$ $\left.{ }^{1}\right)$ and $\left.2000 \mathrm{mg} \mathrm{kg}^{-1}\left(0.0072912 \mathrm{~mol} \mathrm{~L}^{-1}\right)\right]$ (experiment 2) were subjected to regression analysis, and the models were selected by the biological behavior and significance of betas, at $5 \%$ probability using the Genes software (Cruz, 2013).

\section{RESULTS AND DISCUSSION}

\section{Experiment 1: Adventitious rooting of different types of adult cuttings from $P$. mucronata cultivated in greenhouse}

The statistical analysis showed significant differences ( $p>0.01$ ) between the means of the different cuttings for all but one characteristic (survival).
The leafless cuttings with two nodes of $P$. mucronata showed the highest survival $(90.6 \%)$, rooting $(85.9 \%)$, root number (6.6), largest root length $(8.0 \mathrm{~cm})$ and more budding $(85.9 \%)$ (Table 1), which show its potential for the production of plants, considering its greater efficiency in the quality of the root system (root number, root length, root volume and root dry mass per cutting) and the production of buds for shoot formation. The ability of this species to root without leaves on the cuttings is a very important characteristic, for preventing the cutting water loss by dehydration, which compromises their survival, with the advantage of not needing an irrigation system, by intermittent misting, which increases costs of the process. With the species Ligustrum sinense Lour. the presence of leaves in the cuttings is not necessary for the adventitious rooting process (Bona et al., 2002).

According to Alexandre et al. (2014), cuttings with one leaf and one node of $P$. mucronata grown in a greenhouse had $65.47 \%$ rooting and 2.36 roots with $5.98 \mathrm{~cm}$ long, without using growth regulators. In this work, rooting of $P$. mucronata cuttings with one leaf and one node showed $59.3 \%$ rooting and 2.1 roots with $4.8 \mathrm{~cm}$ long without application of auxin (Table 1). However, Alexandre et al. (2014) reported that the use of IBA increased linearly up to the concentration of $1000 \mathrm{mg} \mathrm{kg}^{-1}$ ( or $0.0036456 \mathrm{~mol} \mathrm{~L}^{-1}$ ), the rooting $(86.07 \%)$, number $(12.26)$ and the length $(8.48$ $\mathrm{cm})$ of roots.

The leafless cuttings with two nodes showed less callusing on its bottom end $(12.5 \%)$, indicating that the rooting process had more direct than indirect effect (Table 1). However, there is the assumption that, in shoot tip cuttings, the large amount of calli $(70.3 \%)$ formed on the bottom end (Table 1) is of the non-friable type, which does not allow the formation of organogenic structures, either from vegetative origin or, the more expected, from root origin. This cell disruption can interfere with the rooting process by constricting the xylem and phloem and thus restraining root emission, even for longer time than the cutting survival.

Rooting of leafless cuttings with two nodes of $P$. mucronata is possible without growth regulators (Table 1). Stem cuttings of 'Boysenberry' (hybrid between 'Marionberry' and raspberry) also need not be treated with IBA to stimulate adventitious rooting (Tiberti et al., 2012). The rooting of blackberry root cuttings also occurs without the use of IBA (Campagnolo \& Pio, 2012). According to Silva et al. (2012), stem cuttings of raspberry give better results than root cuttings and do not require treatment with IBA. In other species such as Pinus taeda (Alcantara et al., 2008) and Rubus fruticosus L. (Tadeu et al., 2012), the rooting percentage decreases with the supply of IBA.

Corroborating our findings, cuttings without and with leaves of other species, for example, Dalbergia sissoo, 
presented $72.0 \%$ and $35.0 \%$ of rooting, respectively (Singh et al., 2012). In other Passifloraceae species such as $P$. actinia Hook., P. serrato-digitata L., and P. setacea DC, the presence of two or three nodes did not result in statistically significant differences in the number of rooted and budded cuttings (Braga et al., 2006). On the other hand, cuttings with three leaves and three nodes of $P$. nitida Kunth, $P$. giberti, $P$. edulis, and $P$. setacea presented $21.32 ; 37.21 ; 26.48$ and $6.76 \%$ of rooting, respectively, without the use of auxin (Roncatto et al., 2008).

The cuttings with two leaves and two nodes, despite the low rooting percentage $(58.3 \%)$, had one of the best results for root number $(6.0)$, root volume $\left(0.77 \mathrm{~cm}^{3}\right)$, and root dry mass $(0.73 \mathrm{~g})$ and were not significantly different from the leafless cuttings with two nodes (Table 1). The high response of volume and dry mass of roots found in cuttings with two leaves and two nodes is probably due to the presence of leaves on the cutting, which maintains the photosynthetic activity and produces assimilates for the formation and growth of the root system and also promotes the growth of secondary roots, increasing its volume.

In african mahogany (Khaya anthotheca (Welw.) C.DC. and $K$. ivorensis A. Chev., cuttings with one node and leaves of larger leaf area $\left(30-50 \mathrm{~cm}^{2}\right)$ showed greater rooting (Opuni-Frimpong et al., 2008). Santos et al. (2012a) reported that $P$. cincinnata cuttings with two or three knots and half of the leaf per cutting planted in Bioplant ${ }^{\circledR}$ substrate showed the greatest root length. The same substrate was used in this study with $P$. mucronata species and was also efficient for the growth of roots (Table 1).

The phenotypic correlation coefficients of the characteristisc in Table 2 were rated on the basis of the scales given by Carvalho et al. (2004) as follows: budding $(\%)$ vs. rooting (\%) with $\mathrm{f}=0.992$, as very strong; budding (\%) vs. root number with $\mathrm{f}=0.927$, as very strong; budding $(\%)$ vs. mean root length $(\mathrm{cm})$ with $\mathrm{rf}=0.995$, as very strong; and budding (\%) vs. root volume $\left(\mathrm{cm}^{3}\right)$ with $\mathrm{rf}=0.804$, as strong. These results allow us to infer that for the experimental conditions applied, the increase of budded cuttings also increases rooting and the number, length and volume of roots. Moreover, through visual observation (bud emissions), it is possible to predict the rooting behavior of P. mucronata cuttings nondestructively, which is very important to ensure the success of the propagation process.

Thus, it is likely that the production of buds has not competed for the carbohydrate sources of cuttings and

Table 1: Survival (SUR,\%), callusing (CALL, \%), rooting (ROOT,\%), number of roots per cutting (NRC), length of largest root $(\mathrm{LLR}, \mathrm{cm})$, shoots $(\mathrm{SHOOT}, \%)$, root volume $\left(\mathrm{RV}, \mathrm{cm}^{3}\right)$, and root dry mass (MDM, g) for different types of $P$. mucronata cuttings

\begin{tabular}{lcccccccc}
\hline \multicolumn{7}{c}{ Characteristics evaluated } \\
\hline Cuttings & $\begin{array}{c}\text { SUR } \\
(\boldsymbol{\%})\end{array}$ & $\begin{array}{c}\text { CALL } \\
(\boldsymbol{\%})\end{array}$ & $\begin{array}{c}\text { ROOT } \\
(\boldsymbol{\%})\end{array}$ & $\mathbf{N R C}$ & $\begin{array}{c}\text { LLR } \\
(\mathbf{c m})\end{array}$ & $\begin{array}{c}\text { SHOOT } \\
(\boldsymbol{\%})\end{array}$ & $\begin{array}{c}\text { RV } \\
\left(\mathbf{c m}^{\mathbf{3}}\right)\end{array}$ & $\begin{array}{c}\text { MDM } \\
(\mathbf{g})\end{array}$ \\
\hline Apex & $87.5 \mathrm{a}^{*}$ & $70.3 \mathrm{a}$ & $17.1 \mathrm{c}$ & $0.5 \mathrm{~b}$ & $2.1 \mathrm{c}$ & $1.5 \mathrm{~b}$ & $0.063 \mathrm{~d}$ & $0.041 \mathrm{c}$ \\
2 leaves and 2 node & $93.7 \mathrm{a}$ & $45.8 \mathrm{a}$ & $58.3 \mathrm{~b}$ & $6.0 \mathrm{a}$ & $5.1 \mathrm{~b}$ & $64.5 \mathrm{a}$ & $0.77 \mathrm{a}$ & $0.73 \mathrm{a}$ \\
1 leafand 1 node & $87.5 \mathrm{a}$ & $56.2 \mathrm{a}$ & $59.3 \mathrm{ab}$ & $2.1 \mathrm{~b}$ & $4.8 \mathrm{~b}$ & $25.0 \mathrm{~b}$ & $0.41 \mathrm{bc}$ & $0.35 \mathrm{bc}$ \\
Without leavesand 2 node & $90.6 \mathrm{a}$ & $12.5 \mathrm{~b}$ & $85.9 \mathrm{a}$ & $6.6 \mathrm{a}$ & $8.0 \mathrm{a}$ & $85.9 \mathrm{a}$ & $0.59 \mathrm{ab}$ & $0.47 \mathrm{ab}$ \\
Without leavesand 1 node & $75.0 \mathrm{a}$ & $8.3 \mathrm{~b}$ & $70.8 \mathrm{ab}$ & $2.3 \mathrm{~b}$ & $5.6 \mathrm{ab}$ & $68.7 \mathrm{a}$ & $0.23 \mathrm{~cd}$ & $0.092 \mathrm{c}$ \\
\hline SDM & 20.8 & 31.5 & 27.2 & 3.1 & 2.6 & 32.3 & 0.27 & 0.316 \\
\hline CV $(\%)$ & 10.9 & 37.3 & 21.4 & 41.1 & 23.3 & 30.1 & 30.9 & 42.84 \\
\hline
\end{tabular}

* Means followed by the same letter in the column are not significantly different by the Tukey test at $5 \%$ probability.

Table 2: Phenotypic correlation coefficients between the characteristics survival (SUV, \%), callusing (CALL, \%), rooting (ROOT, \%), number of roots per cutting (NRC), length of largest root (LLR, cm), shoots (SHOOT, \%), root volume (RV, $\left.\mathrm{cm}^{3}\right)$, and root dry mass (RDM, g) with different types of P. mucronata cuttings

\begin{tabular}{|c|c|c|c|c|c|c|c|c|}
\hline $\begin{array}{l}\text { Characteristics } \\
\text { evaluated }\end{array}$ & SUV (\%) & CALL $(\%)$ & $\operatorname{ROOT}(\%)$ & NRC & $\operatorname{LLR}(\mathbf{c m})$ & SHOOT (\%) & $\mathbf{R V}\left(\mathbf{c m}^{3}\right)$ & $\operatorname{RDM}(\mathbf{g})$ \\
\hline SUV (\%) & - & $0.678^{\mathrm{ns}}$ & $-0.571^{\mathrm{ns}}$ & $-0.149^{\mathrm{ns}}$ & $-0.507^{\mathrm{ns}}$ & $-0.508^{\mathrm{ns}}$ & $0.088^{\mathrm{ns}}$ & $0.475^{\mathrm{ns}}$ \\
\hline CALL $(\%)$ & & - & $-0.987^{* * *}$ & $-0.826^{*}$ & $-0.975^{* *}$ & $-0.976^{* *}$ & $-0.659^{\mathrm{ns}}$ & $-0.306^{\mathrm{ns}}$ \\
\hline ROOT (\%) & & & - & $0.891^{* *}$ & $0.996^{* *}$ & $0.992^{* *}$ & $0.757^{*}$ & $0.459^{\mathrm{ns}}$ \\
\hline NRC & & & & - & $0.922^{* *}$ & $0.927^{* *}$ & $0.963^{* *}$ & $0.816^{*}$ \\
\hline $\operatorname{LLR}(\mathrm{cm})$ & & & & & - & $0.995^{* *}$ & $0.797^{*}$ & $0.508^{\mathrm{ns}}$ \\
\hline SHOOT (\%) & & & & & & - & $0.804^{*}$ & $0.528^{\mathrm{ns}}$ \\
\hline $\mathrm{RV}(\%)$ & & & & & & & - & $0.952^{* *}$ \\
\hline RDM (g) & & & & & & & & - \\
\hline
\end{tabular}

${ }^{\mathrm{ns}}$ Non significant, ${ }^{*},{ }^{* *}$ significant at 5 and $1 \%$ probability by the $\mathrm{t}$ test, respectively.

Rev. Ceres, Viçosa, v. 63, n.5, p. 691-697, set/out, 2016 
has not caused a negative effect on adventitious rooting. Bud emission is actually an important signal to measure the efficiency of $P$. mucronata cuttings in producing and promoting root growth. In addition, the meristematic region of shoots and buds is the site of auxin synthesis, which can be redirected to the bottom end of the cuttings and promote adventitious rooting (Taiz \& Zeiger, 2009).

\section{Experiment 2: Adventitious rooting of mature cuttings of $P$. mucronata field plantstreated with IBA}

Cuttings of $P$. mucronata field plants treated with IBA had lower survival rates, lower rooting, and smaller length and root dry mass (Figure 1A, B, D and E, respectively). Salomão et al. (2002) found for basal and medium cuttings
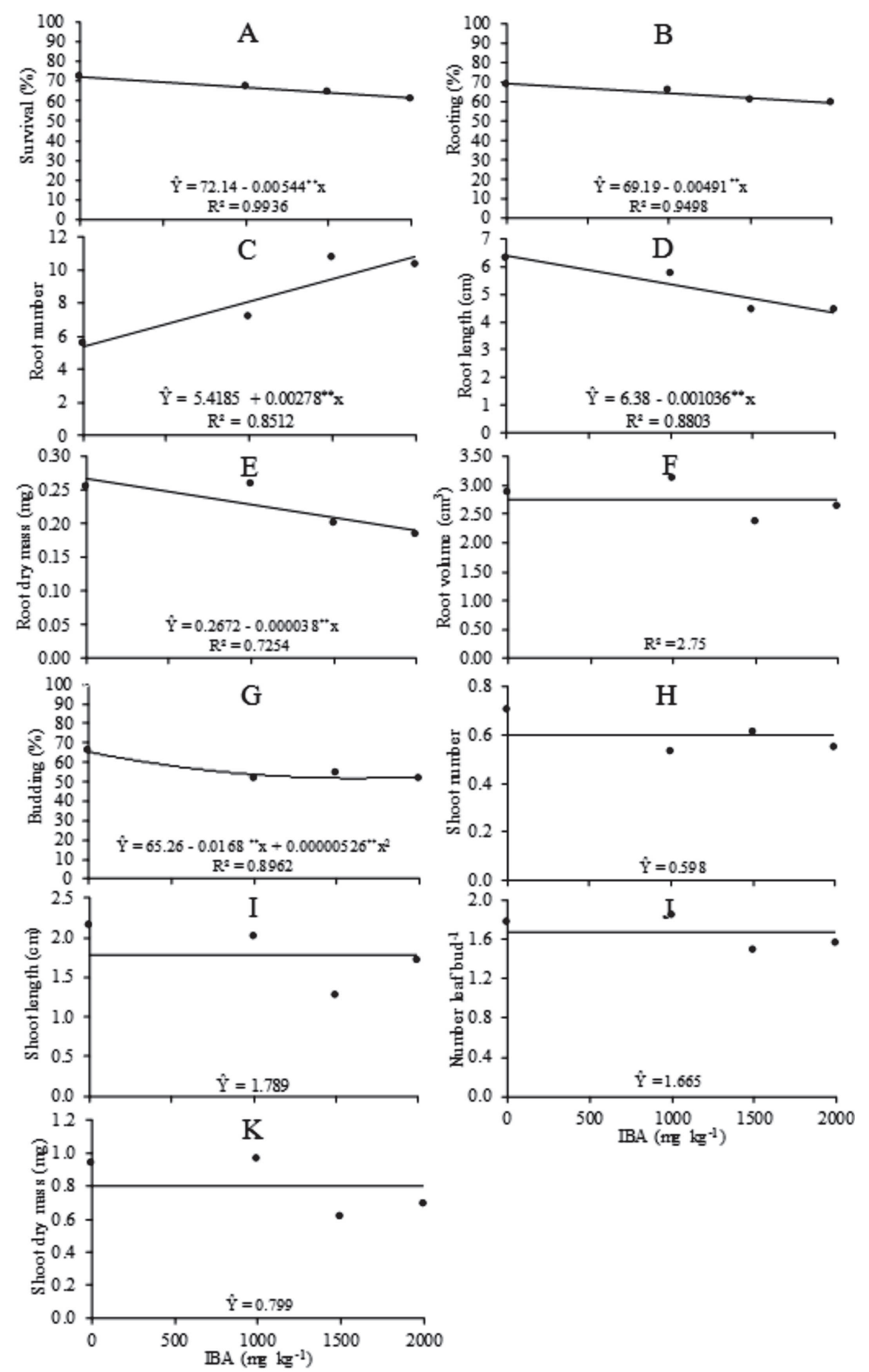

Figure 1: Survival $(\%, A)$, rooting $(\%, B)$, root number $(\mathrm{C})$, root length $(\mathrm{cm}, \mathrm{D})$, root dry weight $(\mathrm{mg}, \mathrm{E})$, root volume $\left(\mathrm{cm}^{3}, \mathrm{~F}\right)$, budding $(\%, \mathrm{G})$, shoot number $(\mathrm{H})$, shoot length $(\mathrm{cm}, \mathrm{I})$, number leaf bud ${ }^{-1}(\mathrm{~J})$ and shoot dry mass $(\mathrm{mg}, \mathrm{K})$ of $P$. mucronata cuttings treated with IBA. ${ }^{* *}$ Significant at $1 \%$ probability. 
that were not treated with auxins rooting percentages of 93 and $94 \%$, for P. alata, and 96\% for P. edulis f. flavicarpa, respectively. Alexandre et al. (2013b) and Sousa et al. (2014) reported that IBA is indispensable for rooting cuttings of P. alata. In Ficus carica L. there is also no need of IBA for the rooting of cuttings (Sousa et al., 2013). Kollaróva et al. (2005) corroborate the finding of this study when they reported that galactoglucomannans oligosaccharides inhibited the length of adventitious roots in mung bean treated with indole acetic acid (IAA). According to these authors, this fact is dependent on the type of the auxin. Mutui et al. (2010) found that IBA reduced the total growth of roots and the root fresh weight in Pelargonium zonale (L.) L'Hér. ex Aiton, which may be related to reduction in ethylene biosynthesis.

The IBA concentrations did not affect the root volume (Figure 1F). Baul et al. (2011) observed that the root number and length of the largest root of Litsea monopetala (Rouxb) cuttings was not significantly different for the different concentrations of IBA. However, the root number was higher with increasing concentrations of IBA, and, in the absence of IBA or at the concentration of $2000 \mathrm{mg} \mathrm{kg}^{-1}$ $\left(0.0072912 \mathrm{~mol} \mathrm{~L}^{-1}\right)$ the production was 5 and 10.97 roots, respectively (Figure 1C). We found that the use of IBA is harmful and not necessary for $P$. mucronata cuttings mainly based on the characteristics mass and volume of roots (Figure $1 \mathrm{E}$ and $\mathrm{F}$, respectively).

The percentage of budding in $P$. mucronata cuttings was lower when using IBA (Figure 1G). The number and length of shoots, number of leaves per shoot and shoot dry mass were not affected by the treatment of $P$. mucronata cuttings with IBA (Figure $1 \mathrm{H}, \mathrm{I}, \mathrm{J}$ and K, respectively). The shoot characteristics were not benefited by the use of auxin, which may have contributed to reduce the endogenous cytokinin/auxin ratio.

\section{CONCLUSIONS}

Leafless cuttings with two nodes are recommended for the propagation of $P$. mucronata.

The rooting of leafless cuttings with two nodes of $P$. mucronata is possible without the use of growth regulators.

The use of shoot tip cuttings is not recommended for adventitious rooting of $P$. mucronata.

IBA is dispensable for the production of $P$. mucronata plants from cuttings.

\section{REFERENCES}

Alcantara GB de, Ribas LLF, Higa AR \& Ribas KCZ (2008) Efeitos do ácido indolilbutírico (AIB) e da coleta de brotações em diferentes estações do ano no enraizamento de miniestacas de Pinus taeda L. Scientia Forestalis, 36:151-156.
Alexandre RS, Costa PR, Chagas K, Mayrinck LG, Detoni JL \& Schmildt ER (2014) Enraizamento adventício de estacas do maracujazeiro silvestre Passiflora mucronataLam.: forma de veiculação e concentrações do ácido indol-3-butírico. Revista Ceres, 61:567-571.

Alexandre RS, Lopes JC, Tiradentes AT, Bruckner CH \& Otoni WC (2013a) Metodologia de minienxertia em maracujazeiros. Revista Brasileira de Fruticultura, 35:329-332.

Alexandre RS, Ferrari, WR, Monterio Junior KR, Chagas K, Schmildt ER \& Gontijo I (2013b) Enraizamento de estacas de genótipos de Passiflora alata Curtis em resposta a ausência e presença de ácido indol-3-butírico (AIB). Revista de Ciências Agrárias, 56:287-291.

Barros AAM de, Ribas L de A \& Araujo DSD (2009) Trepadeiras do Parque Estadual da Serra da Tiririca, Rio de Janeiro, Brasil. Rodriguésia, 60:681-694.

Baul TK, Hossain MM, Mezbahuddin M \& Mohiuddin M (2011). Vegetative propagation of Litsea monopetala, a wild tropical medicinal plant: effects of indole-3-butyric acid (IBA) on stem cutting. Journal of Forestry Research, 22:409-416.

Bona CM de, Höger Filho G, Augusto CSS \& Biasi LA (2002) Propagação de Ligustrum sinense por estaquia semilenhosa. Scientia Agraria, 3:25-28.

Boscolo OH \& Valle L de S (2008) Planta de uso medicinal em Quissamã, Rio de Janeiro, Brasil. Iheringia. Série Botânica, 63:263-277.

Braga MF, Santos EC dos, Junqueira NTV, Sousa AATC de, Faleiro FG, Rezende LN \& Junqueira KP (2006) Enraizamento de estacas de três espécies silvestre de Passiflora. Revista Brasileira de Fruticultura, 28:284-288.

Campagnolo MA \& Pio R (2012) Enraizamento de estacas caulinares e radiculares de cultivares de amoreira-preta coletadas em diferentes épocas, armazenadas a frio e tratadas com AIB. Ciência Rural, 42:232-237.

Carvalho FIF, Lorencetti C \& Benin G (2004) Estimativas e implicações da correlação no melhoramento vegetal. Pelotas: Editora e Gráfica Universitária - UFPel, 141p.

Cruz CD (2013) Genes: a software package for analysis in experimental statistics and quantitative genetics. Acta Scientiarum. Agronomy, 35:271-276.

Fachinello JC, Hoffmann A, Nachtigal JC, Kersten E \& Fontes G de RL (1995) Propagação de plantas frutíferas de clima temperado.Pelotas: UFPel, 178p.

Hartmann HT, Kester DE, Davies Júnior FT \& Geneve RL (2002) Plant propagation: principles and practices. 7. ed. New Jersey: Prentice Hall, 880 p.

Junqueira NTV, Braga MF, Faleiro FG, Peixoto, JR \& Bernacci LC (2005) Potencial de espécies silvestres de maracujazeiro como fonte de resistência a doenças. In: Faleiro FG, Junqueira NTV \& Braga MF Maracujá: germoplasma e melhoramento genético. Planaltina: Embrapa Cerrados, p.81-106.

Kollárova K, Henselóva M \& Lišková D (2005). Effect of auxins and plant oligosaccharides on root formation and elongation growth of mung bean hypocotyls. Plant Growth Regulation, 46:1-9.

Lourenço Junior J, Zambom O, Rossi MS \& Cuzzuol GRF (2013) Effects that nutritional and saline gradients have on the growth of Passiflora mucronata Lam. and Canavalia rosea (Sw.) DC. found in the restinga of Brazil. Acta Botânica Brasílica, 27:318326. 
Magnago LFS, Martins SV \& Pereira OJ (2011) Heterogeneidade florística das fitocenoses de restingas nos estados do Rio de Janeiro e Espírito Santo. Revista Árvore, 35:245-254.

Meletti LMM, Soares-Scott MD, Bernacci LC, Alvares V \& Azevedo Filho JA de (2011) Caracterização de Passiflora mucronataLam.: nova alternativa de maracujá ornamental. Revista Brasileira de Horticultura Ornamental, 17:87-95.

Morgado MAD, Bruckner, CH, Rosado LDS\& Santos CEM (2015) Desenvolvimento de mudas de maracujazeiro-azedo enxertadas em espécies silvestres de Passiflora. Revista Brasileira de Fruticultura, 37: 471-479.

Mutui TM, Mibus H \& Serek M (2010). The influence of plant growth regulators and storage on root induction and growth in Pelargonium zonale cuttings. Plant Growth Regulation, 61:185193

Oliveira MVA de, Santos Junior PV, Santos TM dos, Xavier AA, Ribeiro RCF \& Bruckner CH (2013) Avaliação da resistência de Passiflora mucronata a Fusarium spp. In: VII Fórum de Ensino, Pesquisa, Extensão e Gestão (VII FEPEG), Montes Claros. VII Fórum de Ensino, Pesquisa, Extensão e Gestão (VII FEPEG), CD-ROM.

Opuni-Frimpong E, Karnosky DF, Storer AJ \& Cobbinah JR (2008) Key roles of leaves, stockplant age and auxin concentration in vegetative propagation of two African mahoganies: Khaya anthotheca Welw. and Khaya ivorensis A. Chev. New Forests, 36:115-123.

Roncatto G, Nogueira Filho GC, Ruggiero C, Oliveira, JC \& Martins ABG (2008) Enraizamento de estacas herbáceas de diferentes espécies de maracujazeiro. Revista Brasileira de Fruticultura, 30:1094-1099.

Salomão LCS, Pereira WE, Duarte RCC \& Siqueira DL (2002) Propagação por estaquia dos maracujazeiros doce (Passiflora alata Dryand.) e amarelo (P. edulis f. flavicarpa O. Deg.). Revista Brasileira de Fruticultura, 24:163-167.
Santos JL, Matsumoto SN, D'Arêde LO, Luz IS da \& Viana AES (2012) Propagação vegetativa de estacas de Passiflora cincinnata Mast. em diferentes recipientes e substratos comerciais. Revista Brasileira de Fruticultura, 34:581-588.

Santos TM dos, Flores PS, Oliveira SP de, Silva DFP da \& Bruckner CH (2012) Tempo de armazenamento e métodos de quebra de dormência em sementes do maracujá-de-restinga. Revista Brasileira de Agropecuária Sustentável, 2:26-31.

Silva KN, Pio R, Tadeu MH, Assis CN de, Curi PN, Moura PHA \& Patto LS (2012) Produção de mudas de framboeseira negra por diferentes métodos de propagação vegetativa. Ciência Rural, 42:418-422.

Singh B, Yadav R \& Bhatt BP (2012) Vegetative propagation of Dalbergia sissoo: effect of growth regulators, length, position of shoot and type of cuttings on rooting potential in stem cuttings. Forestry Studies in China, 14:187-192.

Sousa CM, Busquet RN, Vasconcellos MAS \& Miranda RM (2013) Effects of auxin and misting on the rooting of herbaceous and hardwood cuttings from the fig tree. Revista Ciência Agronômica, 44:334-338.

Sousa CM, Santos MP dos \& Carvalho BM (2014) Enraizamento de estacas de maracujazeiro-doce (Passiflora alata Curtis). Científica, 42:68-73.

Tadeu MH, Pio R, Tiberti AS, Figueiredo MA de \& Souza FBM de (2012) Enraizamento de estacas caulinares e radiculares de Rubus fruticosus tratadas com AIB. Revista Ceres, 59:881-884.

Taiz L \& Zeiger E (2009) Fisiologia Vegetal. 3. ed. Porto Alegre: Artmed. p.465.

Tiberti AS, Pio R, Assis CN, Silva KN \& Tadeu MH (2012) Propagação do 'Boysenberry' por estaquia e mergulhia. Ciência Rural, 42:423-428. 